\title{
Pengaruh Giberelin Terhadap Karakter Morfologi dan Hasil Buah Partenokarpi pada Tujuh Genotipe Tomat (Solanum lycopersicum L.)
}

\section{The Effect of Gibberellin on Parthenocarpic Fruit Morphology and Yield of Seven Tomato Genotypes (Solanum lycopersicum L.)}

\author{
Agus Budi Setiawan ${ }^{1}$, Rudi Hari Murti ${ }^{2 *}$, Aziz Purwantoro ${ }^{2}$ \\ ${ }^{1}$ Mahasiswa Program Pascasarjana, Program Studi Pemuliaan Tanaman, Fakultas Pertanian \\ Universitas Gadjah Mada
Staf Pengajar Program Pascasarjana, Program Studi Pemuliaan Tanaman, Fakultas Pertanian, \\ Universitas Gadjah Mada, Jalan Flora Bulaksumur Yogyakarta 55281 Indonesia
}

*email: rhmurti@ugm.ac.id

\begin{abstract}
Gibberellin is plant growth regulator that regulated growth and development of tomato fruit. Parthenocarpic fruit can be induced by gibberellin. The aim of this research is to determined the response of seven tomato genotypes to $\mathrm{GA}_{3}$ application on fruit set, fruit size and fruit yield. The research was conducted at green house of UPTD Balai Pengembangan Perbenihan Tanaman Pangan dan Hortikultura, Yogyakarta and Genetics and Plant Breeding Laboratory started from October 2014 to February 2015. Factorial 7 genotypes $x 2 G_{3}$ concentrations was arranged in Randomized complete block design with 3 replications. Non-emasculated flowers was sprayed with $\mathrm{GA}_{3}$ started on first cluster of first flower (stage 12) with the interval 3 days for 6 applications. The results showed that B78 is the responsive genotype to $\mathrm{GA}_{3}$, which increased locular cavity up to 6 (locul/fruit) and had highly reduced of fruit set $(81.96 \%)$ in respect to seeded fruit. Gamato 1 is the most responsive genotype to $\mathrm{GA}_{3}$ application for inducing parthenocarpy whose fruit weight per cluster had the lowest reduction (28,38\%) and fruit length $(41.68 \mathrm{~mm})$ and diamater $(46.11 \mathrm{~mm})$ were greater than other genotypes. Parthenocarpic fruit of A65, Gamato 3, A175, Gamato 5 and Kaliurang 206 had the reduction of fruit size and yield compared to seeded fruit.
\end{abstract}

Keywords: Parthenocarpic fruit, GA 3 Effect, Tomato Fruit, Tomato Genotype.

\section{INTISARI}

Giberelin merupakan zat pengatur tumbuh yang berperan dalam pertumbuhan dan perkembangan buah tomat. Buah partenokarpi dapat diinduksi dengan menggunakan giberelin. Penelitian ini bertujuan untuk menentukan respon tujuh genotipe tomat terhadap $\mathrm{GA}_{3}$ terkait karakter fruit set, ukuran, dan hasil buah tomat. Penelitian ini dilakukan di Green House UPTD Balai Pengembangan Perbenihan Tanaman Pangan dan Hortikultura, Dinas Pertanian Pemerintah Daerah Istimewa Yogyakarta serta Laboratorium Genetika dan Pemuliaan Tanaman, Fakultas Pertanian, UGM mulai bulan Oktober 2014 hingga Februari 2015. Penelitian menggunakan rancangan faktorial 7 genotipe $\mathrm{x} 2$ konsentrasi $\mathrm{GA}_{3}$ yang disusun dalam rancangan acak kelompok lengkap dengan 3 blok. Kluster bunga dengan bunga pertama fase 12 yang tidak dikastrasi disemprot $\mathrm{GA}_{3}$ dengan interval 3 hari sekali sebanyak 6 kali. Hasil penelitian menunjukkan bahwa B78 merupakan genotipe yang responsif terhadap $\mathrm{GA}_{3}$ dengan ditandai dengan peningkatan jumlah lokul menjadi 6 (lokul/buah) dan mengalami penurunan fruit set sebesar 81,96\% serta ukuran buah yang menurun secara nyata dibandingkan dengan buah berbiji. Genotipe yang tanggap terhadap aplikasi $\mathrm{GA}_{3}$ untuk menginduksi buah partenokarpi dengan hasil dan ukuran buah yang bagus adalah Gamato 1 ditandai dengan penurunan bobot buah per tandan yang relatif kecil yaitu $28,38 \%$ serta buah partenokarpi yang dihasilkan memiliki ukuran panjang dan diameter buah yang masih jauh lebih besar $(41,68 \mathrm{~mm}$ dan $46,11 \mathrm{~mm})$ dibandingkan genotipe lainnya. Buah partenokarpi A65, Gamato 3, A175, Gamato 5 dan Kaliurang 206 mengalami 
penurunan ukuran (panjang, diameter, dan ketebalan daging buah) serta penurunan hasil buah tomat dibandingkan dengan buah berbiji.

Kata kunci: Buah Partenokarpi, Pengaruh $\mathrm{GA}_{3}$, Buah Tomat, Genotipe Tomat.

\section{PENDAHULUAN}

Buah tanpa biji dapat terbentuk tanpa adanya penyerbukan dan/atau pembuahan, dinamakan partenokarpi (Lukyanenko, 1991). Partenokarpi merupakan karakter yang penting bagi industri, karena biji tidak harus dibuang terlebih dahulu sebelum tahap prosesing (Sato et al., 2004; Rotino et al., 2005). Selain itu, buah tanpa biji memiliki kandungan bahan kering lebih banyak hingga $1 \%$, kandungan gula lebih banyak, keasaman rendah, selulosa rendah, dan memiliki kandungan padatan terlarut lebih banyak daripada tomat berbiji (Lukyanenko, 1991).

Partenokarpi pada tomat dapat diinduksi dengan giberelin (Serrani et al., 2007a; Serrani et al., 2007b). $\mathrm{GA}_{3}$ telah diketahui mampu meningkatkan fruit set dan hasil buah tomat pada konsentrasi yang rendah (Sasaki et al., 2005; Khan et al., 2006). Namun, buah tomat hasil induksi giberelin memiliki ukuran lebih kecil dari pada buah berbiji yang menunjukkan bahwa adanya peranan hormone lain terhadap pertumbuhan dan perkembangan buah tomat (de Jong et al., 2009). Selain perubahan ukuran buah, giberelin juga mempengaruhi pembentukan jumlah lokul atau rongga buah (Sawhney and Dabbs, 1978; Sawhney, 1984; Wien and Zhang, 1991; Liu and $\mathrm{Li}, 2012)$. Jumlah lokul buah tomat berkaitan erat dengan perubahan bentuk buah (malformasi) (Li, 1993). Dengan demikian giberelin akan mempengaruhi ukuran dan hasil buah tomat partenokarpi.

Fakultas pertanian memiliki beberapa galur tomat unggulan hasil pemuliaan tanaman diantaranya galur A65, A131, A134, A175, B52 dan B78. Tiga diantaranya sudah terdaftar di Pusat Perlindungan Varietas Tanaman, Kementerian Pertanian yaitu galur A131 (Gamato 1), Galur A134 (Gamato 3), dan Galur B52 (Gamato 5). Galur- galur tersebut memiliki ukuran buah yang besar dan cocok untuk dikembangkan sebagai tomat untuk olahan industri. Setiawan et al. (2015) menyatakan bahwa keenam genotipe tomat tersebut memiliki derajat partenokarpi yang berbeda. Pada penelitian ini, tujuh genotipe tomat termasuk Kaliurang 206 yang merupakan varietas lokal diuji untuk menentukan respon fruit set, ukuran dan hasil buah partenokarpi pada ketujuh genotipe tersebut terhadap aplikasi giberelin.

\section{BAHAN DAN METODE}

Tanaman tomat (Solanum lycopersicum L.) yang digunakan adalah cv Gamato 1, Gamato 3, Gamato 5, Kaliurang 206 dan galur A65, A175, dan B78. Gamato 1, Penelitian ini dilaksanakan dari bulan Oktober 2014 hingga Februari 2015 di Green House UPTD Balai Pengembangan Perbenihan Tanaman Pangan dan Hortikultura, Dinas Pertanian Pemerintah Daerah Istimewa Yogyakarta, Jl. Kaliurang km 23 Ngipiksari, Hargobinangun,Pakem,Slemanserta Laboratorium Genetika dan Pemuliaan Tanaman, Fakultas Pertanian, UGM. Penelitian menggunakan rancangan faktorial 7 genotipe $\mathrm{x} 2$ konsentrasi $\mathrm{GA}_{3}$ yang disusun dalam rancangan acak kelompok lengkap dengan 3 blok dengan jarak tanam $50 \mathrm{~cm}$ x $60 \mathrm{~cm}$. Standar perawatan agronomi diterapkan selama penanaman.

Kluster bunga dengan bunga pertama fase 12 yang tidak dikastrasi disemprot $\mathrm{GA}_{3}$ (Merck) 20 ppm dan 0 ppm (Kontrol) dengan interval 3 hari sekali sebanyak 6 kali. Fase perkembangan bunga merujuk kepada hasil penelitian Brukhin et al. (2003). Fruitset dihitung berdasarkan jumlah buah per tandan dibagi jumlah bunga per tandan dilakukan terhadap tandan pertama dan kedua pada tiga tanaman di setiap unit percobaan. Pengukuran ketebalan daging buah dilakukan dengan cara membelah buah tomat secara melintang kemudian diukur menggunakan jangka sorong digital. Panjang dan diameter buah diukur menggunakan jangka sorong digital pada tiga buah tomat di setiap tanaman sampel di setiap unit percobaan. Bobot per buah dan bobot buah per tandan ditimbang menggunakan timbangan digital (ADD GF-6100, Jepang, 0,01-6100 g). Jumlah lokul per buah dilakukan dengan membelah buah secara melintang, kemudian dihitung jumlah lokulnya.

Data dianalisis dengan analisis varian dengan tingkat kepercayaan 95\%. Selanjutnya diuji lanjut dengan Duncan Multiple Range Test (DMRT) jika hasil analisis varian menunjukkan adanya interaksi yang nyata antara genotipe tomat dengan 
aplikasi $\mathrm{GA}_{3}$ atau jika hanya faktor tunggalnya saja yang berbeda nyata. Analisis data dilakukan dengan menggunakan software SAS 9.3.

\section{HASIL DAN PEMBAHASAN}

Giberelin merupakan zat pengatur tumbuh yang memiliki peranan penting dalam pembentukan dan perkembangan buah tomat (Gorguet et al., 2005). Fruit set menggambarkan persentase keberhasilan buah yang terbentuk. Tabel 1 menunjukkan bahwa terdapat interaksi antara genotipe dan konsentrasi $\mathrm{GA}_{3}$ pada karakter fruit set. Hal ini menunjukkan perbedaan tanggapan antar genotipe terhadap perlakuan $\mathrm{GA}_{3}$. Aplikasi $\mathrm{GA}_{3}$ menyebabkan penurunan fruit set secara nyata. $\mathrm{B} 78$ yang disemprot $\mathrm{GA}_{3}$ mengalami penurunan fruit set paling rendah dibandingkan dengan genotipe lainnya. Sementara fruit set keenam genotipe lainnya tidak dipengaruhi oleh aplikasi giberelin meskipun di Kaliurang 206 pada perlakuan $\mathrm{GA}_{3} 20 \mathrm{ppm}$ menunjukkan fruit set yang lebih tinggi daripada kontrol tapi secara statistik tidak berbeda nyata. Hal ini menunjukkan adanya perbedaan tanggapan pada kaliurang 206 terhadap konsentrasi $\mathrm{GA}_{3}$.

Tabel 1. Pengaruh genotipe dan aplikasi giberelin terhadap fruit set (\%)

\begin{tabular}{|c|c|c|c|c|c|c|c|c|}
\hline \multirow{2}{*}{ Konsentrasi } & \multicolumn{7}{|c|}{ Genotipe } & \multirow{2}{*}{ Rerata } \\
\hline & A65 & Gamato 1 & Gamato 3 & A175 & Gamato 5 & B78 & Kaliurang 206 & \\
\hline $0 \mathrm{ppm}$ & $77,51 \mathrm{a}$ & $82,43 a$ & $78,72 \mathrm{a}$ & $83,30 \mathrm{a}$ & $68,33 \mathrm{a}$ & $83,55 a$ & $69,85 a$ & 77,67 \\
\hline $20 \mathrm{ppm}$ & $63,94 a$ & $65,27 \mathrm{a}$ & $76,66 a$ & $65,11 \mathrm{a}$ & $63,13 a$ & $15,07 \mathrm{~b}$ & $75,04 \mathrm{a}$ & 60,60 \\
\hline Rerata & 70,73 & 73,85 & 77,69 & 74,21 & 65,73 & 49,31 & $72,04 a$ & + \\
\hline
\end{tabular}

Keterangan: Nilai dalam kolom dan baris yang diikuti oleh huruf yang sama menunjukkan tidak berbeda nyata berdasarkan uji Duncan pada tingkat kepercayaan 95\%. (+) menunjukkan ada interaksi.

Hasil penelitian ini sesuai dengan Andyesuari (2014) yang menyatakan bahwa tidak ada pengaruh yang signifikan akibat $\mathrm{GA}_{3}$ terhadap fruit set di Gamato 3 dan Kaliurang 206. Gelmesa et al. (2012) melaporkan bahwa fruit set pada tomat yang diberi perlakuan $\mathrm{GA}_{3} 20 \mathrm{ppm}$ lebih rendah daripada fruit set pada tomat dengan perlakuan $\mathrm{GA}_{3} 5 \mathrm{ppm}, 10 \mathrm{ppm}$, dan kontrol. Perlakuan $\mathrm{GA}_{3}$ hanya meningkatkan fruit set pada perlakuan $5 \mathrm{ppm}$ dan $10 \mathrm{ppm}$ dibandingkan dengan kontrol. Tabel 1 menunjukkan bahwa konsentrasi $\mathrm{GA}_{3} 20$ ppm tidak menunjukkan pengaruh yang nyata terhadap fruit set keenam genotipe selain B78. B78 yang disemprot $\mathrm{GA}_{3}$ menunjukkan respon penurunan fruit set yang sangat besar $(81,96 \%)$.

Ukuran buah sangat bergantung kepada pengaturan perimbangan antara giberelin dan auksin. Buah tomat tersusun atas dua atau lebih karpel, yang dipisahkan oleh septum yang berasal dari fusi dua dinding karpel yang berdekatan (perikarp). Perikarp terletak berdekatan dengan rongga buah (locullar cavity) yaitu tempat biji menempel pada plasenta yang berdekatan dengan columella (Gillaspy et al., 1993). Perikarp tersusun atas eksokarp, mesokarp, dan endokarp (Lemaire-Chamley et al., 2005). Tabel 2 menunjukkan bahwa tidak terdapat interaksi antara genotipe dan konsentrasi $\mathrm{GA}_{3}$ terhadap ketebalan daging buah (pericarp). Ketebalan daging buah (pericarp) secara signifikan dipengaruhi oleh genotipe. Gamato 1, A175, dan B78 memiliki daging buah yang lebih tebal meski secara statistik tidak berbeda nyata dengan A65, Gamato 3 dan Gamato 5. Kaliurang 206 memiliki perikarp yang lebih tipis berbeda nyata dibandingkan dengan genotipe lainnya.

Tabel 2. Pengaruh genotipe dan aplikasi giberelin terhadap ketebalan daging buah (mm)

\begin{tabular}{cccccccccc}
\hline \multirow{2}{*}{ Konsentrasi } & \multicolumn{7}{c}{ Genotipe } & \multirow{2}{*}{ Rerata } \\
\cline { 2 - 9 } & A65 & Gamato 1 & Gamato 3 & A175 & Gamato 5 & B78 & Kaliurang 206 & \\
\hline $0 \mathrm{ppm}$ & 4,82 & 5,61 & 5,25 & 5,82 & 5,31 & 5,59 & 4,03 & $5,21 \mathrm{p}$ \\
$20 \mathrm{ppm}$ & 3,88 & 5,27 & 4,17 & 4,99 & 4,60 & 4,87 & 3,33 & $4,44 \mathrm{q}$ \\
\hline Rerata & $4,35 \mathrm{ab}$ & $5,44 \mathrm{a}$ & $4,71 \mathrm{a}$ & $5,41 \mathrm{a}$ & $4,96 \mathrm{a}$ & $5,23 \mathrm{a}$ & $3,68 \mathrm{~b}$ & - \\
\hline
\end{tabular}

Keterangan: Nilai dalam kolom atau baris yang diikuti oleh huruf yang sama menunjukkan tidak berbeda nyata berdasarkan uji Duncan pada tingkat kepercayaan 95\%. (-) menunjukkan tidak ada interaksi. 
Giberelin berpengaruh nyata terhadap ketebalan daging buah. Bunga tomat yang diaplikasikan $\mathrm{GA}_{3}(20 \mathrm{ppm})$ memiliki daging buah yang lebih tipis daripada kontrol (0 ppm). Hasil penelitian ini kebalikan dengan penelitian Serrani et al. (2007a) yang menyatakan bahwa perikarp buah hasil induksi $\mathrm{GA}_{3}$ lebih tebal daripada buah hasil polinasi. Penurunan ketebalan daging buah pada perlakuan $\mathrm{GA}_{3} 20 \mathrm{ppm}$ diduga karena kandungan auksin yang rendah di dalam ovarium dibandingkan dengan kontrol (0 ppm). Auksin diperlukan untuk pembelahan sel dan meningkatkan pembentukan jumlah sel. Kandungan auksin dan $\mathrm{GA}_{3}$ di dalam ovarium meningkat setelah terjadinya polinasi dan pembuahan (Mapelli et al., 1978; Sjut and Bangerth, 1982; Koshioka et al., 1994) sehingga adanya peningkatan jumlah sel dan pembesaran sel yang diatur oleh auksin dan giberelin pada kontrol mengakibatkan perikarp lebih tebal daripada perlakuan GA3 20 ppm.

Bentuk dan ukuran buah ditentukan oleh panjang dan diameter buah. Tabel 3 dan 4 menunjukkan tidak terdapat interaksi antara genotipe dan konsentrasi $\mathrm{GA}_{3}$ untuk karakter panjang dan diameter buah. Kedua karakter tersebut nyata dipengaruhi oleh konsentrasi $\mathrm{GA}_{3}$. Perlakuan $20 \mathrm{ppm}$ menghasilkan panjang dan diamater buah yang lebih kecil daripada kontrol. Karakter panjang buah tidak dipengaruhi oleh genotipe, sementara diameter buah dipengaruhi secara nyata oleh genotipe. Gamato 1 memiliki diameter buah yang paling besar dibandingkan dengan genotipe lainnya tapi tidak berbeda nyata dengan B78 dan Gamato 5. Diameter buah kedua genotipe tersebut tidak berbeda nyata dengan A65, A175, Gamato 3, dan Kaliurang 206.

Tabel 3. Pengaruh genotipe dan aplikasi giberelin terhadap panjang buah (mm)

\begin{tabular}{ccccccccc}
\hline \multirow{2}{*}{ Konsentrasi } & \multicolumn{7}{c}{ Genotipe } & \multirow{2}{*}{ Rerata } \\
\cline { 2 - 9 } & A65 & Gamato 1 & Gamato 3 & A175 & Gamato 5 & B78 & Kaliurang 206 & \\
\hline $0 \mathrm{ppm}$ & 42,83 & 47,98 & 40,84 & 47,86 & 42,97 & 44,01 & 37,13 & $43,38 \mathrm{p}$ \\
$20 \mathrm{ppm}$ & 34,13 & 41,68 & 34,68 & 23,69 & 29,71 & 31,49 & 28,46 & $31,98 \mathrm{q}$ \\
\hline Rerata & $38,49 \mathrm{a}$ & $44,84 \mathrm{a}$ & $37,76 \mathrm{a}$ & $35,78 \mathrm{a}$ & $36,34 \mathrm{a}$ & $37,75 \mathrm{a}$ & $32,80 \mathrm{a}$ & - \\
\hline
\end{tabular}

Keterangan: Nilai dalam kolom atau baris yang diikuti oleh huruf yang sama menunjukkan tidak berbeda nyata berdasarkan uji Duncan pada tingkat kepercayaan 95\%. (-) menunjukkan tidak ada interaksi.

Tabel 4. Pengaruh genotipe dan aplikasi giberelin terhadap diameter buah (mm)

\begin{tabular}{ccccccccc}
\hline & \multicolumn{9}{c}{ Genotipe } & \\
\cline { 2 - 7 } & A65 & Gamato 1 & Gamato 3 & A175 & Gamato 5 & B78 & Kaliurang & Rerata \\
\hline $0 \mathrm{ppm}$ & 37,77 & 51,39 & 34,49 & 39,36 & 45,21 & 44,51 & 42,36 & $42,16 \mathrm{p}$ \\
$20 \mathrm{ppm}$ & 29,66 & 46,11 & 26,95 & 20,53 & 33,34 & 35,67 & 30,39 & $31,81 \mathrm{q}$ \\
\hline Rerata & $33,71 \mathrm{~b}$ & $48,75 \mathrm{a}$ & $30,72 \mathrm{~b}$ & $29,95 \mathrm{~b}$ & $39,28 \mathrm{ab}$ & $40,09 \mathrm{ab}$ & $36,39 \mathrm{~b}$ & - \\
\hline
\end{tabular}

Keterangan: Nilai dalam kolom atau baris yang diikuti oleh huruf yang sama menunjukkan tidak berbeda nyata berdasarkan uji Duncan pada tingkat kepercayaan 95\%. (-) menunjukkan tidak ada interaksi.

Hasil penelitian menunjukkan bahwa giberelin mengakibatkan penurunan ukuran buah (panjang dan diameter) dibandingkan dengan buah tanaman kontrol. Hasil penelitian ini sesuai dengan hasil penelitian Bunget-Kibler and Bangerth (1983) dan Serrani et al. (2007a) yang menyatakan bahwa buah tomat hasil induksi giberelin memiliki ukuran buah yang lebih kecil dibandingkan buah tomat berbiji. Hal ini disebabkan buah partenokarpi hasil induksi $\mathrm{GA}_{3}$ memiliki jumlah sel yang lebih sedikit dibandingkan dengan buah yang dipolinasi, meskipun ukuran sel hasil perlakuan $\mathrm{GA}_{3}$ lebih besar (Serrani et al., 2007a).
Hasil buah pada tanaman tomat ditentukan oleh jumlah bobot buah per tandan dan bobot per buah. Tidak terdapat interaksi antara genotipe dengan konsentrasi $\mathrm{GA}_{3}$ untuk kedua parameter tersebut. Bobot per buah (Tabel 5) dan bobot buah per tandan (Tabel 6) dipengaruhi secara nyata oleh genotipe. Gamato 1 memiliki bobot per buah yang paling tinggi $(124,27$ gram). Hal ini dikarenakan Gamato 1 memiliki ketebalan pericarp, panjang dan diameter buah yang paling besar dibandingkan genotipe lainnya (Tabel 2, 3, dan 4).

Perlakuan $\mathrm{GA}_{3} 20$ ppm berpengaruh nyata menurunkan bobot per buah (Tabel 5) dan bobot 
buah per tandan (Tabel 6). Perlakuan kontrol memiliki bobot per buah dan bobot buah per tandan yang lebih besar daripada perlakuan $\mathrm{GA}_{3}$ $20 \mathrm{ppm}$. Hal ini disebabkan oleh rendahnya fruit set pada perlakuan giberelin. Selain itu, hasil buah tomat ditentukan oleh fruit set serta jumlah sel dan ukuran buah (Ariizumi et al., 2013).

Tabel 5. Pengaruh genotipe dan aplikasi giberelin terhadap bobot per buah (gram)

\begin{tabular}{cccccccccc}
\hline \multirow{2}{*}{ Konsentrasi } & \multicolumn{7}{c}{ Genotipe } & \multirow{2}{*}{ Rerata } \\
\cline { 2 - 9 } & A65 & Gamato 1 & Gamato 3 & A175 & Gamato 5 & B78 & Kaliurang 206 & \\
\hline $0 \mathrm{ppm}$ & 74,06 & 125,10 & 68,32 & 69,66 & 69,26 & 112,80 & 82,73 & $85,99 \mathrm{p}$ \\
$20 \mathrm{ppm}$ & 51,88 & 123,43 & 41,91 & 52,62 & 57,88 & 59,64 & 50,65 & $62,57 \mathrm{q}$ \\
\hline Rerata & $62,97 \mathrm{bc}$ & $124,27 \mathrm{a}$ & $55,12 \mathrm{c}$ & $61,15 \mathrm{c}$ & $63,57 \mathrm{bc}$ & $86,22 \mathrm{~b}$ & $66,69 \mathrm{bc}$ & - \\
\hline
\end{tabular}

Keterangan: Nilai dalam kolom atau baris yang diikuti oleh huruf yang sama menunjukkan tidak berbeda nyata berdasarkan uji Duncan pada tingkat kepercayaan 95\%. (-) menunjukkan tidak ada interaksi.

Tabel 6. Pengaruh genotipe dan aplikasi giberelin terhadap bobot buah per tandan (gram)

\begin{tabular}{|c|c|c|c|c|c|c|c|c|}
\hline \multirow[b]{2}{*}{ Konsentrasi } & \multicolumn{7}{|c|}{ Genotipe } & \multirow[b]{2}{*}{ Rerata } \\
\hline & A65 & Gamato 1 & Gamato 3 & A175 & Gamato 5 & B78 & $\begin{array}{c}\text { Kaliurang } \\
206\end{array}$ & \\
\hline $0 \mathrm{ppm}$ & 271,81 & 531,22 & 267,77 & 270,81 & 243,68 & 424,72 & 311,66 & $331,67 p$ \\
\hline $20 \mathrm{ppm}$ & 161,03 & 380,43 & 131,05 & 182,79 & 139,95 & 177,86 & 167,34 & $191,50 \mathrm{q}$ \\
\hline Rerata & $216,42 b$ & $455,83 a$ & $199,41 b$ & $226,81 \mathrm{~b}$ & $191,82 b$ & $301,29 b$ & $239,50 \mathrm{~b}$ & - \\
\hline
\end{tabular}

Keterangan: Nilai dalam kolom atau baris yang diikuti oleh huruf yang sama menunjukkan tidak berbeda nyata berdasarkan uji Duncan pada tingkat kepercayaan 95\%. (-) menunjukkan tidak ada interaksi

Lokul merupakan rongga yang terdapat di dalam buah, terletak di antara perikarp dan plasenta (Ho and Hewitt, 1986). Jumlah lokul dipengaruhi oleh interaksi genotipe dan konsentrasi $\mathrm{GA}_{3}$. Genotipe B78 pada perlakuan $\mathrm{GA}_{3} 20$ ppm memiliki jumlah lokul paling banyak dibandingkan genotipe lainnya, tapi tidak berbeda nyata dengan Gamato 1 pada perlakuan kontrol. Semua genotipe tidak menunjukkan perbedaan yang signifikan antara perlakuan kontrol dan $\mathrm{GA}_{3} 20$ ppm kecuali pada B78.
Pengaruh konsentrasi $\mathrm{GA}_{3}$ terhadap jumlah lokul di setiap genotipe hanya spesifik berpengaruh nyata pada genotipe B78 (Tabel 7). Konsentrasi $\mathrm{GA}_{3} \quad 20 \mathrm{ppm}$ mengakibatkan peningkatan jumlah lokul dibandingkan dengan kontrol 0 ppm (Gambar 1). Hasil ini sesuai dengan Liu and $\mathrm{Li}$ (2012) yang menyatakan bahwa setiap genotipe tomat memiliki respon yang berbeda terhadap giberelin untuk pembentukan jumlah lokul.

Tabel 7. Pengaruh genotipe dan aplikasi giberelin terhadap jumlah lokul per buah

\begin{tabular}{cccccccccc}
\hline \multirow{2}{*}{ Konsentrasi } & \multicolumn{7}{c}{ Genotipe } & \multirow{2}{*}{ Rerata } \\
\cline { 2 - 9 } & A65 & Gamato 1 & Gamato 3 & A175 & Gamato 5 & B78 & Kaliurang 206 & \\
\hline $0 \mathrm{ppm}$ & $2,78 \mathrm{f}$ & $5,39 \mathrm{ab}$ & $2,78 \mathrm{f}$ & $2,81 \mathrm{f}$ & $2,92 \mathrm{ef}$ & $3,94 \mathrm{~d}$ & $3,72 \mathrm{de}$ & 3,48 \\
$20 \mathrm{ppm}$ & $2,61 \mathrm{f}$ & $4,78 \mathrm{bc}$ & $2,56 \mathrm{f}$ & $2,92 \mathrm{ef}$ & $3,11 \mathrm{ef}$ & $5,83 \mathrm{a}$ & $4,39 \mathrm{~cd}$ & 3,74 \\
\hline Rerata & 2,69 & 5,08 & 2,67 & 2,86 & 3,01 & 4,89 & 4,06 & + \\
\hline
\end{tabular}

Keterangan: Nilai dalam kolom dan baris yang diikuti oleh huruf yang sama menunjukkan tidak berbeda nyata berdasarkan uji Duncan pada tingkat kepercayaan 95\%. (+) menunjukkan ada interaksi.

Giberelin telah diketahui mampu meningkatkan jumlah lokul pada tanaman tomat (Sawhney and Dabbs, 1978; Sawhney, 1984; Wien and Zhang, 1991; Liu and Li, 2012). Hal ini disebabkan karena giberelin mampu menekan ekspresi gen fasciated yang mengendalikan jumlah lokul (Liu and Li, 2012). Tanskley (2004) menyatakan bahwa perubahan ukuran buah dan jumlah lokul pada tomat domestikasi karena terjadi mutasi pada salah satu gen fasciated atau locule number dan/atau pada kedua gen tersebut. Cong et al. (2008) menambahkan bahwa fasciated mengendalikan jumlah karpel selama perkembangan bunga dan/atau buah tomat.

Hasil penelitian ini menunjukkan bahwa tujuh genotipe tomat memiliki tanggapan fruit set yang 
berbeda-beda terhadap $\mathrm{GA}_{3}$. Pada dasarnya, fruit set semua genotipe pada perlakuan kontrol tidak mampu mencapai $100 \%$. Hal ini menunjukkan bahwa dalam kondisi normal terdapat pengaruh lingkungan yang mempengaruhi fruit set. A65, Gamato 1, Gamato 3, A175, dan Gamato 5 menunjukkan penurunan fruit set meski secara statistik tidak berbeda nyata. Kaliurang 206 menunjukkan respon sebaliknya, fruit set pada perlakuan $\mathrm{GA}_{3} 20 \mathrm{ppm}$ lebih tinggi daripada kontrol meski secara statistik tidak berbeda nyata. Sementara B78 mengalami penurunan fruit set yang nyata pada perlakuan $\mathrm{GA}_{3} 20 \mathrm{ppm}$.

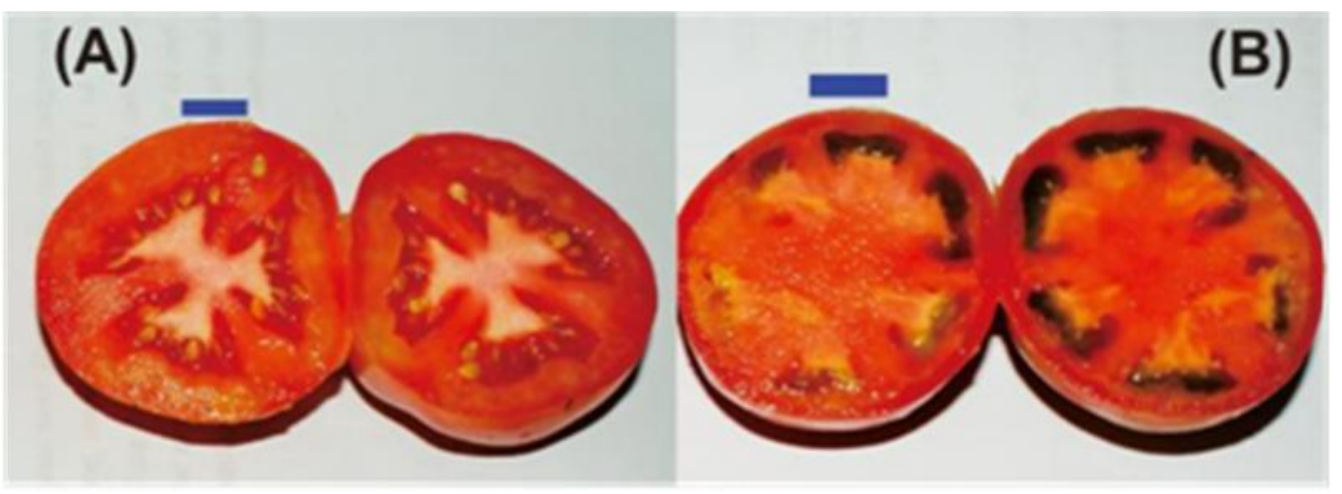

Gambar 1. Perubahan jumlah lokul akibat giberelin pada genotipe B78. (A) B78 perlakuan GA3 0 ppm, (B) B78 perlakuan GA3 20 ppm. Garis biru $(1 \mathrm{~cm})$.

Ketebalan daging buah pada perlakuan $\mathrm{GA}_{3}$ 20 ppm memiliki ukuran yang lebih tipis dibandingkan perlakuan kontrol. Penurunan ketebalan daging buah pada tomat yang diaplikasikan $\mathrm{GA}_{3}$ diduga karena kandungan auksin yang rendah di dalam ovarium dibandingkan dengan perlakuan kontrol. Selain itu, Vriezen et al. (2008) membandingkan profil ekspresi gen dari ovarium yang diserbuki dan ovarium yang diberi perlakuan giberelin. Gen yang berasosiasi dengan siklus sel lebih kuat diinduksi oleh perlakuan polinasi daripada giberelin. Beberapa gen yang terlibat dalam ekspansi sel sama-sama diinduksi baik pada perlakuan polinasi dan perlakuan $\mathrm{GA}_{3}$. Namun beberapa dari gen tersebut seperti SIEXPA5 nampak lebih tinggi ekspresinya setelah polinasi (Vriezen et al., 2008). Meskipun demikian, Gamato 1 yang disemprot $\mathrm{GA}_{3}$ memiliki panjang buah yang masih jauh lebih besar $(41,68 \mathrm{~mm})$ dibandingkan genotipe lainnya yang berkisar antara 23,69 mm - 34,68 mm. Demikian juga dengan diameter buah yang lebih besar $(46,11 \mathrm{~mm})$ dari genotipe lainnya yang berkisar antara 20,53 $\mathrm{mm}-35,67 \mathrm{~mm}$.

Efek giberelin terhadap morfologi buah juga ditemukan berpengaruh terhadap ukuran buah (panjang dan diameter buah) dan bobot buah. Giberelin secara nyata menurunkan ukuran buah dan mempengaruhi bobot buah. Penurunan ukuran buah mengakibatkan penurunan hasil buah. Namun, dari genotipe yang diuji, Gamato 1 memiliki penurunan bobot buah per tandan yang relatif kecil yaitu $28,38 \%$. Sementara genotipe yang lain berkisar antara $32,50-58,12 \%$. Selain itu, Gamato 1 termasuk kategori low-seeded, yang berarti genotipe tersebut memiliki jumlah biji yang sedikit jika diberi perlakuan $\mathrm{GA}_{3}$ dengan penurunan jumlah biji mencapai $83,83 \%$ (Setiawan et al., 2015). Maka Gamato 1 termasuk genotipe yang responsif terhadap $\mathrm{GA}_{3}$ dan sangat cocok dikembangkan sebagai genotipe untuk induksi buah partenokarpi dengan $\mathrm{GA}_{3}$. Perlu dikaji lebih lanjut mengenai tanggapan ketujuh genotipe tersebut dengan kombinasi aplikasi $\mathrm{GA}_{3}$ dan auksin untuk menghasilkan buah partenokarpi agar menekan penurunan hasil dan ukuran buah.

\section{KESIMPULAN}

B78 merupakan genotipe yang responsif terhadap $\mathrm{GA}_{3}$ ditandai dengan peningkatan jumlah lokul dan penurunan fruit set serta ukuran yang besar. Genotipe yang tanggap terhadap aplikasi $\mathrm{GA}_{3}$ untuk menginduksi buah partenokarpi dengan hasil dan ukuran buah yang bagus adalah Gamato 1. Buah partenokarpi mengalami penurunan ukuran (panjang, diameter, dan ketebalan daging buah) serta penurunan hasil buah tomat dibandingkan dengan buah berbiji. 


\section{DAFTAR PUSTAKA}

Adnyesuari, A. A. 2014. Induksi Partenokarpi Buah Tomat dengan $\mathrm{GA}_{3}$. Skripsi: Universitas Gadjah Mada.

Ariizumi, T., Shinozaki, Y., and Ezura, H. 2013. Genes that influence yield in tomato. Breding Science 63: 3-13.

Brukhin, V., Hernould, M., Gonzalez, N., Chevalier, C., and Mouras, A. 2003. Flower development schedule in tomato Lycopersicon esculentum cv. sweet cherry. Sex Plant Reprod 15: 311-320.

Bunger-Kibler, S. and Bangerth, F. 1982. Relationship between cell number, cell size and fruit size of seeded fruits of tomato (Lycopersicon esculentum Mill.), and those induced parthenocarpically by the application of plant growth regulators. Plant Growth Regul 1:143-154.

Cong, B., Barrero, L.S., and Tanksley, S.D. 2008. Regulatory change in YABBY-like transcription factor led to evolution of extreme fruit size during tomato domestication. Nature Genetics 40: 800-804.

de Jong, M., Mariani, C., and Vriezen, W. H. 2009. The role of auxin and gibberellin in tomato fruit set. Journal of Experimental Botany 60: 1523-1532.

Gelmesa, D., Abebie, B., and Desalegn, L. 2012. Regulation of tomato (Lycopersicon esculentum Mill.) fruit setting and earliness by gibberellic acid and 2,4- dichlorophenoxy acetic acid application. African Journal of Biotechnology 11: 11200-11206.

Gillaspy, G., Bendavid, H., and Gruissem, W. 1993. Fruits: a developmental perspective. Plant Cell 5:1439-1451.

Gorguet, B., van Heusden, A. W., and Lindhout, P. 2005. Parthenocarpic fruit development in tomato. Plant Biology 7: 131-139.

Ho, L.C. and Hewitt, J.D. 1986. Fruit development. In: Atherton JG, Rudich J, editors. The tomato crop: a scientific basis for improvement. Cambridge, UK: Cambridge University Press; Chapman and Hall Ltd.

Khan, M.M.A., Gautam, C., Mohammad, F., Siddiqui, M.H., Naeem, M., and Khan, M.N. 2006. Effect of gibberellic acid spray on performance of tomato. Turk. J. Biol. 30: 1116.

Koshioka, M., Nishijima, T., Yamazaki, H., Liu, Y., Nonaka, M., and Mander, L.N. 1994.
Analysis of gibberellins in growing fruits of Lycopersicon esculentum after pollination or treatment with 4-chlorophenoxyacetic acid. Journal of Horticultural Science 69: 171-179.

Lemaire-Chamley, M., Petit, J., Garcia, V., Just, D., Baldet, P., Germain, V., Fagard, M., Mouassite, M., Cheniclet, C., and Rothan, C. 2005. Changes in transcriptional profiles are associated with early fruit tissue specialization in tomato. Plant Physiology 139: 750-769.

Li, T.L. 1993. The Influence of Gibberallic Acid (GA3) on the Forming of Tomato Locules. J. Shenyang Agric. Univ. 24:131-356.

Liu, S. and Li, T.L. 2012. Regulation effects of exogenous gibberellin acid (GA3) on the formation of tomato (Solanum Lycoperscium) ovary locule and fasciated transcription. African Journal of Biotechnology 11: 1373213738.

Lukyanenko, A.N. 1991. Parthenocarpy in tomato. In Monographs on Theoretical and Applied Genetics: Genetics Improvement of Tomato (Kalloo, G., ed.), Springer-Verlag.

Mapelli, S., Frova, C., Tort, G., and Soressi, G. 1978. Relationship between set development and activities of growth regulators in tomato fruit. Plant Cell Physiol 19:1281-1288.

Rotino, G.L., Acciarri, N., Sabatini, E., Mennella, G., Lo Scalzo, R., Maestrelli, A., Molesini, B., Pandolfini, T., Scalzo, J., Mezzetti, B., and Spena, A. 2005. Open field trial of genetically modified parthenocarpic tomato: Seedlessness and fruit quality. BMC Biotechnol. 5: 32.

Sasaki, H., Yano, T., and Yamasaki, A. 2005. Reduction of high temperature inhibition in tomato fruit set by plant growth regulators. JARQ, 39: 135-138.

Sato, S., Peet, M.P., Gardner, R.G. 2004. Altered flower retention and developmental patterns in nine tomato cultivars under elevated temperature. Scientia Horticulturae 101: 95101.

Sawhney, V.K. 1984. Gibberellins and fruit formation in tomato: a review. Scientia Horticulturae 22: 1-8.

Sawhney, V.K. and Dabbs, D.H. 1978. Gibberellic acid induced multilocular fruits in tomato and the role of locule number and seed number in fruit size. Can. J. Bot 56: 28312835.

Serrani, J. C, Fos, M., Atare's, A., and GarcíaMartı'nez, J. L. 2007a. Effect of gibberellin 
and auxin on parthenocarpic fruit growth induction in the cv micro- tom of tomato. $\mathrm{J}$ Plant Growth Regul 26:211-221.

Serrani, J. C, Sanjuan, R., Rivero. O.R., Fos, M., and Garc1'a-Martı'nez, J. L. 2007b. Gibberellin regulation of fruit set and growth in Tomato. Plant Physiology 145: 246-257.

Sjut, V., and Bangerth, F. 1982. Induced parthenocarpy - a way of changing the levels of endogenous hormones in tomato fruits (Lycopersicon esculentum Mill.). 1. Extractable hormones. Plant Growth Regul 1: 243-251.

Setiawan, A.B., Murti, R.H., and Purwantoro, A. 2015. Seedlessness and fruit quality traits of
GA-induced parthenocarpic fruit in seven tomato genotypes (Solanum lycopersicum L.). Unpublished manuscript.

Tanksley, S.D. 2004. The genetic, developmental, and molecular bases of fruit size and shape variation in tomato. Plant Cell 16: S181-S189.

Wien, H.C. and Zhang, Y. 1991. Gibberellic acid foliar sprays show promise as screening tool for tomato fruit catfacing. Hort Science 26: 583-585.

Vriezen, W.H., Feron, R., Maretto, F., Keijman, J., and Mariani, C. 2008. Changes in tomato ovary transcriptome demonstrate complex hormonal regulation of fruit set. New Phytologist.177:60-76. 